7. Reprod. Fert. (1974) 38, 11-20

\title{
MAINTENANCE OF PREGNANCY IN RATS ON DEFICIENT DIETS*
}

\author{
L. L. ANDERSON, J. J. FORD AND R. M. MELAMPY \\ Department of Animal Science, Iowa State University, \\ Ames, Iowa 50010, U.S.A.
}

(Received 25th April 1973)

\begin{abstract}
Summary. After mating, rats were fed one of the following diets: $100 \%$ sucrose, $100 \%$ vitamin-free casein, purified protein-free or purified with $20 \%$ casein. Fetal survival and weight changes in the maternal adrenal glands, uterus, ovaries and gastrocnemius muscle were determined at Day 20. Pregnancy failed in all animals fed sucrose or a protein-free diet and in half of those fed purified casein. Daily injections of progesterone $(5 \mathrm{mg}$ ) increased both the number of rats remaining pregnant and fetal survival rates in those fed sucrose, a protein-free diet or casein. Pregnancy maintenance in these animals was characterized by larger adrenal glands and smaller gastrocnemius weights. The failure of pregnancy in rats fed only vitamin-free casein or a protein-free diet was associated with a significant increase in loss of total body weight. The minimum period of progesterone treatment for the maintenance of pregnancy was Days 5 to 9 in dams fed only sucrose after mating. In animals fed sucrose, treated with progesterone from Days 5 to 9 and killed on Days 6, 9, 12, 15 and 18, the weights of the uterus and conceptuses began to increase, the weight of the liver declined, followed by a decrease in gastrocnemius weight. Exogenous ACTH or prolactin was inadequate for maintaining viable embryos in ovariectomized rats given a diet of sucrose.
\end{abstract}

\section{INTRODUCTION}

Protein deprivation after mating leads to reproductive failure in the rat (Nelson \& Evans, 1954; Leathem, 1966), but pregnancy can be maintained by exogenous oestrogen and progesterone. It seems that the diminished ovarian activity results from reduced luteotrophic support by the adenohypophysis (Hays \& Kendall, 1961; Callard \& Leathem, 1970). The rôle of progesterone in the mobilization of maternal protein for the developing fetuses and placentae is unknown.

Few investigations have examined the effects of feeding diets deficient in more than one essential nutrient. Pregnancy studies in rats fed only sucrose are

* Journal Paper No. J-7575 of the Iowa Agricultural and Home Economics Experiment Station, Ames, Iowa; Projects No. 1325 and 1712. 
limited to reports by Kendall \& Hays (1960) and Hays, Hahn \& Kendall (1965) who observed that pregnancy was maintained by oestrogen and progesterone. The objective of the present studies was to determine the time course of changes in organ weights associated with the maintenance or the failure of pregnancy. The effects of exogenous progesterone were determined on the maintenance of pregnancy in rats fed diets of $100 \%$ sucrose, $100 \%$ casein or a protein-free diet adequate in all other nutrients. The effects of corticotrophin $(\mathrm{ACTH})$, prolactin and ovarian steroids on embryo survival and the maternal organs were investigated in rats maintained on a diet of sucrose.

\section{MATERIALS AND METHODS}

Female Holtzman-derived rats (SASCO, Omaha, Nebraska) weighing 210 to $250 \mathrm{~g}$ at the time of mating were maintained on a schedule of 12-hr light and 12-hr dark with the temperature at $22 \pm 1^{\circ} \mathrm{C}$. Rats were housed individually in wire-mesh cages, and Purina Laboratory Chow and water were freely available. The diet was supplemented twice weekly with fresh carrots. In the afternoon of pro-oestrus, females were placed with males of proven fertility, and by Day 0 (the day spermatozoa were found in the vaginal smear), females were given one of the following diets: 100\% sucrose (cane sugar), $100 \%$ vitamin-free casein (General Biochemicals Inc.), purified protein-free or purified protein-free with $20 \%$ casein. Progesterone $(20 \mathrm{mg} / \mathrm{ml})$ and oestrone $(4 \mu \mathrm{g} / \mathrm{ml})$ were dissolved in sesame oil, and each female was injected once daily subcutaneously on the designated days. The composition of the $20 \%$ casein diet was: ingredients listed as $\mathrm{g} / \mathrm{kg}$, sucrose, 697; casein (vitamin-free), 200; dextrin, 28; salt mix (Hegsted), 40; safflower oil, 30; DL-methionine, 3; ingredients listed as $\mathrm{mg} / \mathrm{kg}$, D-biotin, 0.3 ; menadione (vitamin $\mathrm{K}-3$ ), 5 ; thiamine $\mathrm{HCl}, 10$; pyridoxine $\mathrm{HCl}$, 5; folic acid, 5.5; riboflavin, 10; p-aminobenzoic acid, 10; niacin, 20; D-pantothenic acid, 50; i-inositol, 400; choline chloride, 1000 ; vitamin B-12, 0.075; L-ascorbic acid, 100; and DL- $\alpha$-tocopherol (1100 i.u. $/ \mathrm{g}), 50$. In the protein-free diet, casein and methionine were replaced with an equal amount of sucrose. Vitamins $\mathrm{A}\left(80 \mathrm{i} . u\right.$.) and $\mathrm{D}_{2}$ (8 i.u.) were given orally three times weekly in $0.2 \mathrm{ml}$ corn oil in those animals fed the protein-free diet and the $20 \%$ casein diet.

Rats with spermatozoa in the vaginal smear were placed on the sucrose diet and ovariectomy or sham-ovariectomy was performed on Day 6 . The numbers of implantation sites and corpora lutea were recorded, and only pregnant females continued on the experiment. Hormone treatment began on Day 5 and continued until Day 9 or 19. In certain groups, progesterone $(5 \mathrm{mg} /$ day) and oestrone ( $1 \mu \mathrm{g} /$ day) were injected from Days 10 to 19 . Subcutaneous injections of 2 i.u. ACTH (Armour) were given twice daily. Ovine prolactin (NIH-P-S10) was administered subcutaneously twice daily at a level of 50 i.u.

Pregnant animals were killed on Days 15, 18 or 20, and the fetuses were tested for viability by movement and blood flow after severing the umbilical cord; the weights of the fetuses were recorded after their removal. In all the dams, the following organs were weighed: uterus, adrenals, liver and the right gastrocnemius muscle. 
Rats on the sucrose diet were injected with progesterone in sesame oil ( $5 \mathrm{mg} /$ day) or the vehicle alone $(0.25 \mathrm{ml} / \mathrm{day})$, and the protein content was determined by the method of Lowry, Rosebrough, Farr \& Randall (1951) on the implantation sites and embryos on Days 6 and 9.

The data were analysed by analysis of variance followed by planned linear comparisons.

\section{RESULTS}

The effects of exogenous progesterone on the maintenance of pregnancy in rats fed a diet of sucrose or a protein-free diet are presented in Table 1 . The average initial body weight for each group ranged from 220 to $229 \mathrm{~g}$. In the rats fed on sucrose, a minimum period of progesterone treatment from Days 5 to 9 was required for successful maintenance of pregnancy (Group C). Maintenance of pregnancy was associated with an increase in adrenal weight and a decrease in gastrocnemius and liver weights (Groups $\mathrm{A}+\mathrm{B}$ versus $\mathrm{C}+\mathrm{D}+\mathrm{E}, P<0.01)$. The decline in body weight was similar in all groups of rats fed on sucrose $(P>0.05)$.

In rats fed the protein-free diet, the maintenance of pregnancy was characterized by larger adrenals and smaller gastrocnemius and liver weights $(\mathrm{F}+\mathrm{G}$ versus $\mathrm{H}, P<0.01)$ and by the maintenance of body weight $(\mathrm{F}+\mathrm{G}$ versus $\mathrm{H}, P<0.01 ; \mathrm{F}$ versus $\mathrm{G}, P<0.05)$. The average number of viable fetuses was greater when progesterone was given from Days 5 to 19 compared with treatment from Days 5 to 9 ( $\mathrm{F}$ versus $\mathrm{G}, P<0 \cdot 05$ ). Pregnancy was maintained in five of ten rats (Group I) fed casein and was associated with decreased weight loss $(P<0.05)$, smaller gastrocnemius weight $(P<0.01)$ and increased adrenal weight $(P<0.05)$. The five rats in which pregnancy had failed by Day 20 (Group I) had a body weight change of $-38 \pm 6 \mathrm{~g}$, a total adrenal gland weight of $53 \pm 1 \mathrm{~g}$ and a gastrocnemius weight of $4 \cdot 2 \pm 0 \cdot 1 \mathrm{mg} / \mathrm{g}$ body weight. Pregnant rats consumed $7.6 \pm 0.4 \mathrm{~g}$ casein/day, compared with $7.8 \pm 0.4 \mathrm{~g} /$ day in those in which pregnancy failed. Progesterone treatment (Group J) doubled the number of animals (10/10) in which pregnancy was maintained, whereas dietary intake remained similar $(8 \cdot 0 \pm 0.3 \mathrm{~g} /$ day $)$.

The data in Table 2 illustrate the changes in maternal organ weights observed throughout pregnancy in rats fed on sucrose. The range for the average initial body weight of each group was 223 to $233 \mathrm{~g}$, and pregnancy was confirmed in all animals at laparotomy on Day 6. Progesterone treatment had no evident effect on maternal organ weights during the first 9 days of pregnancy, with the exception of liver weight, which was greater on Day 9 in progesteronetreated animals. By Day 12, the implantation sites had resorbed in those females which received oil only; adrenal weights were less, and liver weights were greater than those in rats treated with progesterone. On Day 15, the rats receiving progesterone had larger ovaries and adrenals and smaller gastrocnemius and liver weights. These differences also were observed on Day 18.

By Day 6, exogenous progesterone had not affected the concentration of protein in the implantation sites $(140 \pm 12$ versus $148 \pm 11 \mu \mathrm{g} /$ implantation site in dams treated with progesterone or the vehicle) in rats maintained on a sucrose diet. The concentration of protein in the embryos at Day 9 was greater 


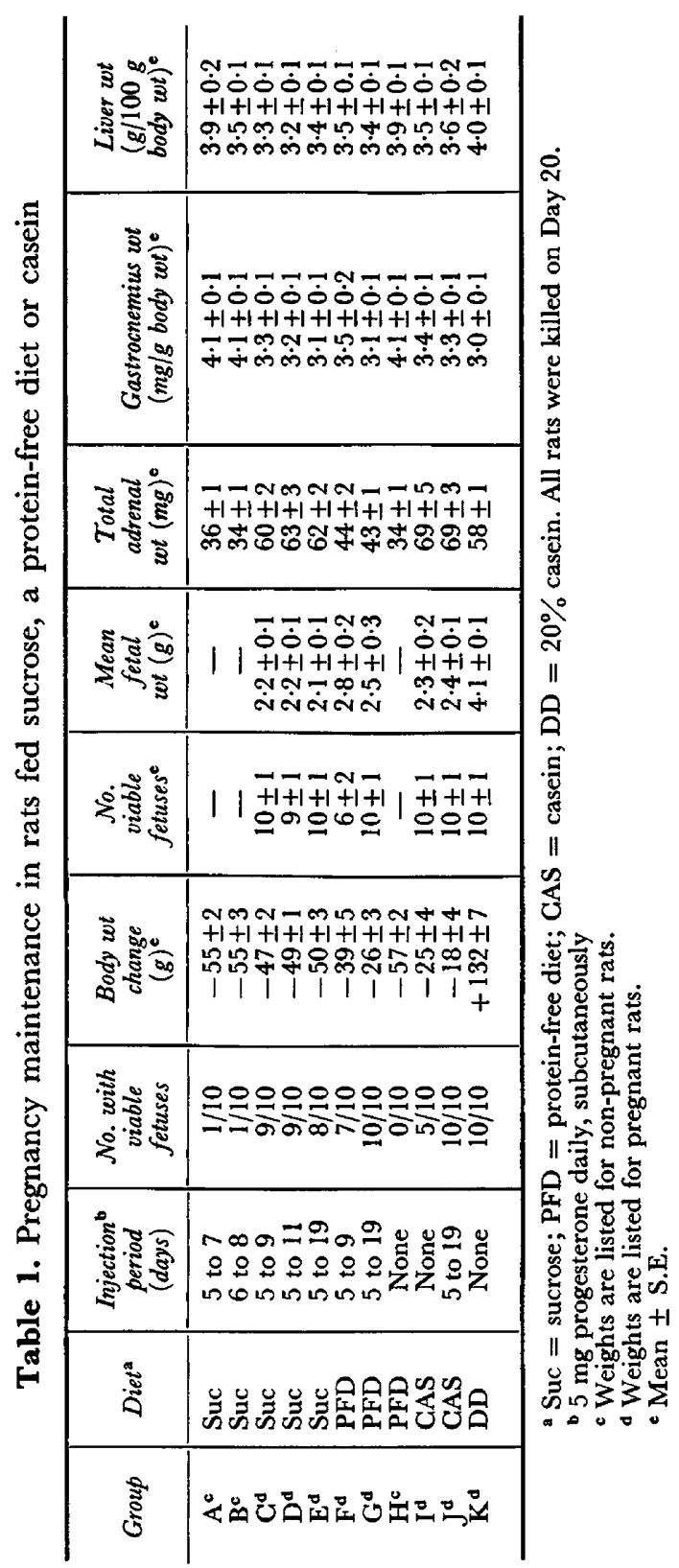


$(P<0.01)$ in the rats treated with progesterone $(21 \pm 2 \mu \mathrm{g} /$ embryo $)$ than that found in the controls $(12 \pm 2 \mu \mathrm{g} / \mathrm{embryo})$.

The effects of corticotrophin, prolactin and ovarian steroids on embryo development and survival as well as in maternal organs in rats maintained on a diet of sucrose are described in Table 3 . The number of implantation sites in all groups of rats was similar on Day 6. Eight of the ten ovariectomized rats given daily injections of progesterone and oestrone between Days 5 and 19 (Group I) had an average of nine viable fetuses on Day 20; Group I served as a control for the other treatment groups. Only six of the ten rats remained pregnant after ovariectomy in those given progesterone (Group II), and embryo survival was reduced considerably (two embryos/dam) as compared with dams

Table 2. Changes with time in rats fed sucrose and treated with progesterone or sesame oil

\begin{tabular}{|c|c|c|c|c|c|c|}
\hline & \multirow[b]{2}{*}{ Treatment ${ }^{\mathbf{a}}$} & \multicolumn{5}{|c|}{ Days after mating ${ }^{\mathrm{d}}$} \\
\hline & & 6 & 9 & 12 & 15 & 18 \\
\hline Body wt $(g)$ & $\begin{array}{l}\text { Prog } \\
\text { Ses }\end{array}$ & $\begin{array}{l}192 \pm 2^{b} \\
198 \pm 3\end{array}$ & $\begin{array}{l}187 \pm 5 \\
193 \pm 3\end{array}$ & $\begin{array}{l}190 \pm 2 * \\
179 \pm 3\end{array}$ & $\begin{array}{l}182 \pm 6 \\
176 \pm 3\end{array}$ & $\begin{array}{l}172 \pm 2 \\
170 \pm 3\end{array}$ \\
\hline $\begin{array}{l}\text { No. of im- } \\
\text { plantation sites }\end{array}$ & $\begin{array}{l}\text { Prog } \\
\text { Ses }\end{array}$ & $\begin{array}{l}10 \pm 1 \\
12 \pm 1\end{array}$ & $\begin{array}{l}13 \pm 1 \\
12 \pm 1\end{array}$ & $\begin{array}{r}12 \pm 2 \\
0\end{array}$ & $\frac{10 \pm 2^{c}}{0}$ & $\frac{9 \pm 1^{c}}{0}$ \\
\hline $\begin{array}{l}\text { Wt of uterus } \\
\text { plus contents }(\mathrm{g})\end{array}$ & $\begin{array}{l}\text { Prog } \\
\text { Ses }\end{array}$ & $\begin{array}{l}0.37 \pm 0.02 \\
0.43 \pm 0.02\end{array}$ & $\begin{array}{l}1.02 \pm 0.07 \\
0.75 \pm 0.12\end{array}$ & $\begin{array}{l}2 \cdot 88 \pm 0.05 * * \\
0.30 \pm 0.04\end{array}$ & $\begin{array}{l}11.2 \pm 1.8 * * \\
0.20 \pm 0.03\end{array}$ & $\begin{array}{l}23 \cdot 6 \pm 3 \cdot 0^{* *} \\
0 \cdot 16 \pm 0 \cdot 01\end{array}$ \\
\hline Ovarian wt (mg) & $\begin{array}{l}\text { Prog } \\
\text { Ses }\end{array}$ & $\begin{array}{l}49 \pm 4 \\
53 \pm 1\end{array}$ & $\begin{array}{l}48 \pm 1 \\
49 \pm 3\end{array}$ & $\begin{array}{l}47 \pm 1 \\
49 \pm 2\end{array}$ & $\begin{array}{l}80 \pm 2 * * \\
49 \pm 3\end{array}$ & $\begin{array}{l}79 \pm 4 * * \\
43 \pm 2\end{array}$ \\
\hline Adrenal wt (mg) & $\begin{array}{l}\text { Prog } \\
\text { Ses }\end{array}$ & $\begin{array}{l}52 \pm 1 \\
49 \pm 2\end{array}$ & $\begin{array}{l}52 \pm 1 \\
50 \pm 2\end{array}$ & $\begin{array}{l}51 \pm 2 * \\
45 \pm 2\end{array}$ & $\begin{array}{l}48 \pm 2 * \\
42 \pm 1\end{array}$ & $\begin{array}{l}52 \pm 2 * * \\
39 \pm 2\end{array}$ \\
\hline $\begin{array}{l}\text { Gastrocnemius } \\
\text { wt (mg/g body wt) }\end{array}$ & $\begin{array}{l}\text { Prog } \\
\text { Ses }\end{array}$ & $\begin{array}{l}4 \cdot 0 \pm 0 \cdot 1 \\
3 \cdot 8 \pm 0.1\end{array}$ & $\begin{array}{l}3 \cdot 9 \pm 0 \cdot 1 \\
3 \cdot 9 \pm 0 \cdot 1\end{array}$ & $\begin{array}{l}3 \cdot 9 \pm 0 \cdot 1 \\
4 \cdot 0 \pm 0 \cdot 1\end{array}$ & $\begin{array}{l}3 \cdot 9 \pm 0 \cdot 1 \\
4 \cdot 1 \pm 0 \cdot 1\end{array}$ & $\begin{array}{l}3 \cdot 6 \pm 0 \cdot 1^{*} \\
3 \cdot 9 \pm 0 \cdot 2\end{array}$ \\
\hline $\begin{array}{l}\text { Liver } w t \\
(\mathrm{~g} / 100 \mathrm{~g} \text { body } w \mathrm{t})\end{array}$ & $\begin{array}{l}\text { Prog } \\
\text { Ses }\end{array}$ & $\begin{array}{l}4 \cdot 2 \pm 0 \cdot 2 \\
4 \cdot 5 \pm 0 \cdot 1\end{array}$ & $\begin{array}{l}4 \cdot 5 \pm 0 \cdot 1 * \\
4 \cdot 1 \pm 0 \cdot 1\end{array}$ & $\begin{array}{l}4 \cdot 1 \pm 0 \cdot 1^{*} \\
4 \cdot 5 \pm 0 \cdot 1\end{array}$ & $\begin{array}{l}3 \cdot 5 \pm 0 \cdot 1 * * \\
4 \cdot 5 \pm 0 \cdot 1\end{array}$ & $\begin{array}{l}3 \cdot 4 \pm 0 \cdot 1 * * \\
4 \cdot 0 \pm 0 \cdot 2\end{array}$ \\
\hline
\end{tabular}

a Prog = progesterone, $5 \mathrm{mg}$ daily, subcutaneously; Ses $=$ sesame oil, $0.25 \mathrm{ml}$ daily, subcutaneously. Injected Days 5 to 9 .

Mean \pm S.E. of six rats.

c Viable fetuses.

- Mean \pm S.E.

* Pairs which are significantly different from one another, $P<0.05$.

** Pairs which are significantly different from one another, $P<0.01$.

given oestrone as well as progesterone (Group I). Pregnancy was maintained in three of ten rats with ovaries in situ with daily injections of $1 \mu \mathrm{g}$ oestrone (Group III) between Days 5 and 9; embryo survival rates were similar to the controls (Group I). Daily injections of oestrone alone in ovariectomized rats (Groups IV and V) were inadequate for the survival of any of the embryos. Only two of ten rats with their ovaries in situ remained pregnant after injection of 4 i.u. ACTH from Days 5 to 9 (Group VI).

Exogenous ACTH failed to induce an adequate level of adrenal steroid secretion for the maintenance of pregnancy in the absence of the gonads (Groups VII and VIII). In ovariectomized rats given ACTH, the numbers remaining pregnant and embryo survival rates were improved by the inclusion of progesterone or progesterone and oestrone (Groups IX and X). Exogenous 


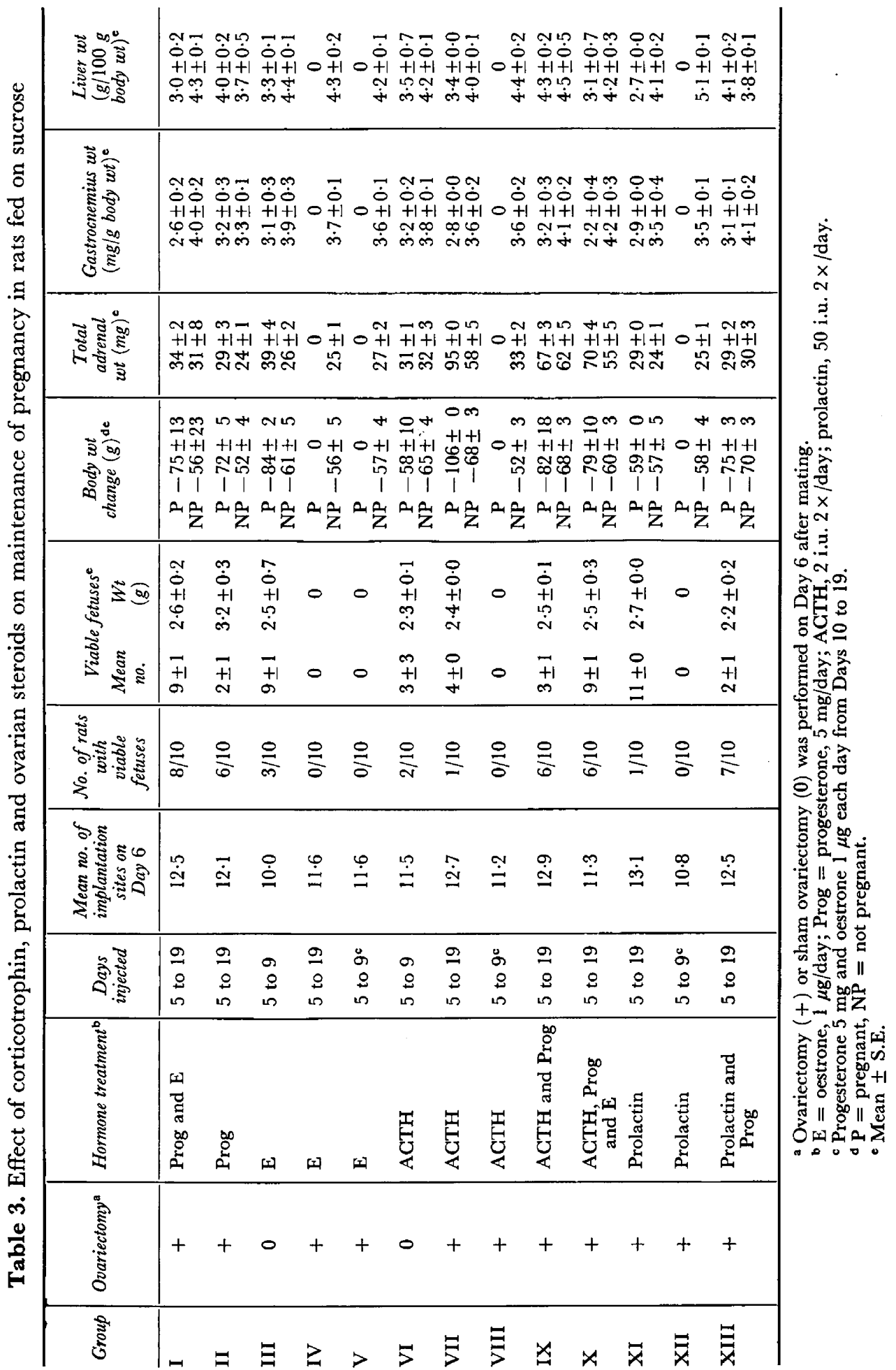


prolactin (100 i.u./day) also failed to maintain pregnancy in ovariectomized dams fed sucrose (Groups XI and XII). The addition of progesterone increased the number of ovariectomized rats remaining pregnant, but embryo survival rates were low (Group XIII). The changes in body weight of the dam, adrenal, gastrocnemius and liver weights are indicated for each group in Table 3.

An analysis of body and organ weight changes in rats maintained on a sucrose diet after mating is presented in Table 4. Those maintaining viable fetuses throughout gestation lost about $18 \mathrm{~g}$ more maternal body weight than dams in which the pregnancy failed. In pregnant rats, adrenal gland weight was higher, whereas both gastrocnemius and liver weights were reduced when compared with non-pregnant rats fed sucrose. Pregnancy was maintained in ovariectomized rats by exogenous progesterone and oestrone; this control

Table 4. Analysis of maternal changes in rats maintained on a sucrose diet after mating

\begin{tabular}{|c|c|c|c|c|c|}
\hline & $\begin{array}{l}\text { No. of } \\
\text { dams }\end{array}$ & $\begin{array}{l}\text { Body wt } \\
\text { change } \\
(g)\end{array}$ & $\begin{array}{l}\text { Adrenal } \\
w t \\
(m g)\end{array}$ & $\begin{array}{c}\text { Gastrocnemius wt } \\
(\mathrm{mg} / \mathrm{g} \text { body } w t)\end{array}$ & $\begin{array}{l}\text { Liver } w t \\
(g / 100 g \\
\text { body } w t)\end{array}$ \\
\hline $\begin{array}{l}\text { Pregnant } \\
\text { Non-pregnant } \\
\quad F \text { value }\end{array}$ & $\begin{array}{l}40 \\
90\end{array}$ & $\begin{array}{l}-77 * * * * \\
-59 \\
25 \cdot 1\end{array}$ & $\begin{array}{l}45 * * * * \\
33 \\
13 \cdot 4\end{array}$ & $\begin{array}{l}2 \cdot 9 * * * * \\
3 \cdot 7 \\
38 \cdot 9\end{array}$ & $\begin{array}{l}3 \cdot 6 * * * * \\
4 \cdot 3 \\
26 \cdot 4\end{array}$ \\
\hline $\begin{array}{l}\text { Progesterone and oestrone } \\
\text { Oestrone } \\
\quad F \text { value }\end{array}$ & $\begin{array}{l}20 \\
30\end{array}$ & $\begin{array}{l}-67 \\
-60 \\
1 \cdot 4\end{array}$ & $\begin{array}{l}31 \\
27 \\
2 \cdot 7\end{array}$ & $\begin{array}{l}3 \cdot 1^{* *} \\
3 \cdot 7 \\
9 \cdot 6\end{array}$ & $\begin{array}{l}3 \cdot 6^{* *} \\
4 \cdot 2 \\
10 \cdot 3\end{array}$ \\
\hline $\begin{array}{l}\text { Progesterone and oestrone } \\
\text { ACTH } \\
F \text { value }\end{array}$ & $\begin{array}{l}20 \\
50\end{array}$ & $\begin{array}{l}-67 \\
-67 \\
0 \cdot 0\end{array}$ & $\begin{array}{l}31 * * * * \\
51 \\
21 \cdot 7\end{array}$ & $\begin{array}{l}3 \cdot 1^{*} \\
3 \cdot 4 \\
3 \cdot 9\end{array}$ & $\begin{array}{l}3 \cdot 6^{*} \\
4 \cdot 1 \\
4 \cdot 0\end{array}$ \\
\hline $\begin{array}{l}\text { Progesterone and oestrone } \\
\text { Prolactin } \\
\quad F \text { value }\end{array}$ & $\begin{array}{l}20 \\
30\end{array}$ & $\begin{array}{l}-67 \\
-63 \\
0 \cdot 6\end{array}$ & $\begin{array}{l}31^{*} \\
26 \\
7 \cdot 2\end{array}$ & $\begin{array}{l}3 \cdot 1 \\
3 \cdot 5 \\
2 \cdot 9\end{array}$ & $\begin{array}{l}3 \cdot 6 * * * * \\
4 \cdot 4 \\
12 \cdot 6\end{array}$ \\
\hline
\end{tabular}

Pairs are significantly different from one another at the level indicated: ${ }^{*} P<0.05 ; * * P<0.01$; $* * * * P<0.001$.

group was compared with those given oestrone, ACTH or prolactin. The pregnancy failed in twenty-seven of the thirty rats which received only oestrone from 5 days after mating, and this was reflected in increased gastrocnemius and liver weights compared to those of the control group. Only fifteen of fifty rats injected with ACTH maintained viable fetuses and this resulted in larger gastrocnemius and liver weights than those found in the pregnant control animals. The exogenous ACTH induced hypertrophy of the adrenal glands (e.g. $+20 \mathrm{mg}$ ). Pregnancy failed in rats given prolactin alone, but when prolactin was combined with progesterone, most rats remained pregnant although embryo survival rate was low. Adrenal gland weights were lower and liver weight was higher in these animals compared with their controls.

\section{DISCUSSION}

Pregnancy was maintained by exogenous progesterone from Days 5 to 9 in rats 
fed sucrose only after mating. The continuation of progesterone treatment after Day 9 did not improve survival rate or growth of the embryos in such rats. Progesterone treatment from Days 5 to 9 was required to maintain pregnancy in rats fed a protein-free diet (Kinzey \& Srebnik, 1963). Callard \& Leathem (1970) suggest that, during this period, protein deprivation diminishes pituitary luteotrophic support before placental luteotrophic secretion is significantly elevated.

The most obvious difference between rats fed sucrose and those given a protein-free diet was the further decline in maternal body weight on the sucrose diet. In intact animals fed sucrose, loss of body weight was independent of pregnancy maintenance. This was in contrast to rats fed a protein-free diet in which pregnancy failure was associated with greater loss of weight. More viable fetuses were observed when progesterone was continued after Day 9 in rats fed the protein-free diet, suggesting that the diet elevated the requirement for progesterone. Hazelwood \& Nelson (1965) found that this loss in maternal weight was not the result of differences in food intake or nitrogen excretion.

Changes in organ weights throughout pregnancy in rats maintained on a diet of sucrose indicated that as the weight of the uterus and its contents begins to increase, the weight of the liver declines, followed by a decrease in gastrocnemius weight. During the last third of pregnancy in rats given a protein diet, there is an abrupt increase in total body weight, which is caused by fetal and placental growth, but little change in maternal weight (Campbell, Innes \& Kosterlitz, 1953). During this period, maternal protein is catabolized independently of the diet received (Hazelwood \& Nelson, 1965; Naismith, 1966). A decrease in skeletal muscle protein has also been observed during pregnancy in the pig (Kline, Anderson \& Melampy, 1972).

Our results indicate that, in sucrose-fed rats, pregnant animals maintain the weight of their adrenal glands through Day 18; then, by Day 20, the adrenal weight increases abruptly. Pregnancy was also associated with elevated adrenal-gland weights in rats fed casein or the protein-free diet. It is probable that the increase after Day 18 results from elevated oestrogen secretion during a period of declining progesterone secretion (Hashimoto, Henricks, Anderson \& Melampy, 1968; Shaikh, 1971). Adrenal weight is elevated by oestrogen treatment and depressed by progesterone treatment (Steinetz, Beach, DiPasquale \& Battista, 1965; Kitay, 1967). The data in Table 3 (Group I), showing that ovariectomized rats receiving a constant level of oestrone had adrenal weights on Day 20 which were approximately half those observed in intact animals (Table 1, Groups C, D and E), supports the view that increased endogenous oestrogen secretion is primarily responsible for elevated adrenal gland weights. Aschkenasy-Lelu \& Aschkenasy (1957) found that the adrenal glands were essential for maintaining pregnancy by daily injections of progesterone in rats fed a protein-deficient diet. Hazelwood \& Nelson (1965) proposed that corticosteroids affected catabolism of maternal protein during pregnancy. Prednisolone, corticosterone and ACTH will maintain pregnancy when administered to rats deprived of protein during the period of proposed luteotrophic insufficiency (Berg, Sigg \& Greengard, 1967; Morishige \& Leathem, 1972). 
Furthermore, ACTH and prednisolone potentiate the effect of ovarian steroids, resulting in improved reproductive performance (Berg \& Carmody, 1971).

Only half the rats remained pregnant on a diet of casein, but pregnancy was maintained by exogenous progesterone in all animals on this diet. As with rats fed the protein-free diet, pregnancy failure in rats fed on casein was associated with increased loss of weight without altering dietary intake.

Exogenous progesterone and oestrone provide essential mechanisms for the conversion of maternal protein for the survival and maturation of fetuses in ovariectomized rats fed only sucrose after mating. When oestrone is absent, some pregnancies fail; successful ones yield an extremely small number of viable fetuses. With the ovaries remaining in situ, exogenous oestrone is partly successful in maintaining pregnancy. Oestrone alone fails to sustain embryonic development in the absence of the ovaries.

\section{ACKNOWLEDGMENTS}

The work was supported by Training Grants HD-00184-04 and -05 from the National Institute of Child Health and Human Development, National Institutes of Health. The authors thank Professor Lotte Arnrich for her counsel in planning experiments, Professor D. F. Cox for assistance with statistical analysis of data, Mr D. W. Brown for animal care and the Endocrinology Study Section, National Institutes of Health for providing prolactin (NIH-P-S10).

\section{REFERENCES}

Aschkenasy-Lelu, P. \& Aschkenasy, A. (1957) Intervention des surrénales dans la gestation en fonction de la teneur du régime en protéines. Archs Sci. physiol. 11, 125.

Berg, B. N. \& CARmody, G. M. (1971) Potentiation of ovarian hormones by ACTH and prednisolone in maintenance of pregnancy after ovariectomy. Endocrinology, 89, 219.

BERG, B. N., Sigg, E. B. \& GReEnGARd, P. (1967) Maintenance of pregnancy in protein-deficient rats by adrenocortical steroid or ACTH administration. Endocrinology, 80, 829 .

Callard, I. P. \& Leathem, J. H. (1970) Pregnancy maintenance in protein deficient rats. Acta endocr., Copenh. 63, 539.

Campbell, R. M., Innes, I. R. \& Kosterlitz, H. (1953) Some dietary and hormonal effects on maternal, foetal and placental weights in the rat. 7. Endocr. 9, 68.

Hays, R. L., Hahn, E. W. \& Kendall, K. A. (1965) Evidence for decreased steroidogenesis in pregnant rats fed a sucrose diet. Endocrinology, 76, 771 .

Hays, R. L. \& Kendall, K. A. (1961) Maintenance of pregnancy with prolactin or progesterone in rats on a sucrose diet. Endocrinology, 68, 177.

Hashimoto, I., Henricks, D. M., Anderson, L. L. \& Melampy, R. M. (1968) Progesterone and pregn-4-en-20 $\alpha$-ol-3-one in ovarian venous blood during various reproductive states in the rat. Endocrinology, 82, 333.

Hazelwood, R. L. \& NeLson, M. M. (1965) Steroid maintenance of pregnancy in rats in the absence of dietary protein. Endocrinology, $\mathbf{7 7}, 999$.

Kendall, K. A. \& HAys, R. L. (1960) Maintained pregnancy in the rat as associated with multiplenutrient deficiency. F. Nutr. 70, 10.

Kinzey, W. G. \& SRebnik, H. H. (1963) Maintenance of pregnancy in protein-deficient rats with short-term injections of ovarian hormones. Proc. Soc. exp. Biol. Med. 114, 158.

KITAY, J. I. (1967) Effects of estrogen and androgen on the adrenal cortex of the rat. In Functions of the Adrenal Cortex, Vol. 2, p. 775. Ed. K. W. McKerns. Appleton-Century-Crofts, New York.

Kline, R. D., Anderson, L. L. \& Melampy, R. M. (1972) Nitrogen retention in pigs during the estrous cycle or pregnancy and after hysterectomy or ovariectomy. F. Anim. Sci. 35, 585.

Leathem, J. H. (1966) Nutritional effects on hormone production. F. Anim. Sci. 25, Suppl., 68.

Lowry, O. H., Rosebrough, N. T., FARR, A. L. \& Randali, R. T. (1951) Protein measurement with the Folin phenol reagent. F. biol. Chem. 193, 265. 
Morishige, W. K. \& Leathem, J. H. (1972) Pregnancy maintenance with corticosterone in proteindepleted rats: a study on fetal protein composition. Endocrinology, 90, 318.

NaIsmith, D. J. (1966) The requirement for protein, and the utilization of protein and calcium during pregnancy. Metabolism, 15, 582.

Nelson, M. M. \& Evans, H. M. (1954) Maintenance of pregnancy in the absence of dietary protein with estrone and progesterone. Endocrinology, 55, 543.

Shaikн, A. A. (1971) Estrone and estradiol levels in the ovarian venous blood from rats during the estrous cycle and pregnancy. Biol. Reprod. 5, 297.

Steinetz, B. G., Beach, V. L., DiPasquale, G. \& Battista, J. V., Jr (1965) Effects of different gestagenic steroid types on plasma-free corticosteroid levels in ACTH-treated rats. Steroids, 5, 93. 